\title{
Effects of various stocking densities on hatching and survival rates of sea cucumber Holothuria tubulosa eggs (Gmelin, 1788)
}

\section{Farklı stok yoğunluklarının deniz hıyarı Holothuria tubulosa (Gmelin, 1788) yumurtalarının açılma ve yaşama oranlarına etkileri}

\author{
Deniz Günay ${ }^{1 *} \bullet$ Mustafa Tolga Tolon ${ }^{2} \bullet$ Dilek Emiroğlu ${ }^{3}$ \\ 'Aquaculture Department, Faculty of Fisheries, Ege University, 35100 Izmir, Turkey (iD https://orcid.org/0000-0003-0069-4703 \\ ${ }^{2}$ Aquaculture Department, Faculty of Fisheries, Ege University, 35100 Izmir, Turkey (iD https://orcid.org/0000-0002-2233-0663 \\ ${ }^{3}$ Aquaculture Department, Faculty of Fisheries, Ege University, 35100 Izmir, Turkey (iD https://orcid.org/0000-0001-8371-6407 \\ *Corresponding author: denizbalki@hotmail.com
}

Received date: 15.05.2018

\section{How to cite this paper:}

Günay, D., Tolon, M.T. \& Emiroğlu, D. (2018). Effects of various stocking densities on hatching and survival rates of sea cucumber Holothuria tubulosa eggs (Gmelin, 1788). Ege Journal of Fisheries and Aquatic Sciences, 35(4), 381-386. DOI: 10.12714/egejfas.2018.35.4.03

Abstract: In this study, it was aimed to determine the opening and survival rates of Holothuria tubulosa eggs at four different stocking densities (1,5,15,30 eggs / $\mathrm{ml})$ and to determine the effect of stocking density on egg size and larval size in different stages. Fertilized Holothuria tubulosa eggs were stocked in cylindrical conical collectors with a capacity of $30 \mathrm{I}$. Eggs were counted under light microscope at fertilization, early gastrulation, late gastrulation and hatching stages. It was found that there is an inverse relationship between stock intensity and opening rate $(r=$ $-0.848 ; \mathrm{p}<0.001)$. The lowest hatching and survival rate was determined in $30 \mathrm{eggs} / \mathrm{ml}$ group $(\mathrm{p}<0.05)$. However, different stocking densities did not affect the diameter of the egg in different embryological stages $(p>0.05)$ and the length of early auricularia larva at $65 \mathrm{~h}(\mathrm{p}>0.05)$. As a result, the optimal stocking density for the highest hatching and survival rates of the fertilized eggs of Holothuria tubulosa was determined as $1-5$ eggs $/ \mathrm{ml}$.

Keywords: Fertilized egg, hatching rate, Holothuria tubulosa, sea cucumber, stocking density, survival

Öz: Bu çalışmada, Holothuria tubulosa yumurtalarının, dört farklı stok yoğunluğunda (1,5,15,30 yumurta/ml) açılma ve yaşama oranlarını belirlemek ve aynı zamanda stok yoğunluğunun farklı evrelerdeki yumurta çapına ve larval boyutuna etkisini ortaya koymak amaçlanmıştır. Döllenmiş Holothuria tubulosa yumurtaları, 30 I hacimli silindir konik kollektörlere stoklanmıştır. Yumurtalar; döllenme anında, erken gastrulasyon, geç gastrulasyon ve yumurtadan çıkma aşamasında mikroskop altında sayılmıştır. Stok yoğunluğu ile açılma oranı arasında ters ilişki olduğu bulunmuştur ( $r=-0.848 ; p<0.001)$. En düşük açılma ve yaşama oranı 30 yumurta/ml stoklandığı deneme grubunda saptanmıştır ( $<<0.05)$. Ancak farklı stok yoğunlukları farklı embriyolojik safhalardaki yumurtanın çapını ( $p>0.05$ ) ve 65. saatteki erken auricularia larvasının boyunu ( $p>0.05$ ) etkilememiştir. Sonuç olarak, Holothuria tubulosa'nın döllenmiş yumurtalarının en yüksek açılma ve yaşama oranları için optimum stoklama yoğunluğu 1-5 yumurta / ml olmuştur.

Anahtar kelimeler: Döllenmiş yumurta, açılma oranı, Holothuria tubulosa, deniz hıyarı, stok yoğunluğu, yaşama oranı 


\section{INTRODUCTION}

Fresh and processed sea cucumbers (beche-demer) are being used as luxury food and food supplement for several centuries (Asha and Diwakar, 2013; Choo, 2008). Increasing demand for beche-de-mer all over the world has been caused excessive fishing and extinction of natural stocks (Purcell et al., 2013). Depending on the movement and feeding activities of sea cucumbers which is resulting as regulation of both oligotrophic and hypereutrophic environments (İşgören-Emiroğlu and Günay, 2007), extinction of these species may reversely affect the recovery process of marine sediments.

Aquaculture studies on sea cucumber species have been carried out in the Far East and Asian countries for several years (Gamboa et al., 2005, Tuwo and Tresnati, 2015). The amount of sea cucumbers provided by aquaculture has been increased by six times between the years 2003 and 2015, while catch amount has been stabilized during the last five years. FAO (2017) has reported 208104 tons and 43216 tons of sea cucumber production from aquaculture and fisheries for 2015, respectively. Holothuria scabra is the most valuable (Raison, 2008) and the most commonly cultured tropical sea cucumber species (Purcell et al., 2012) followed by Apostichopus japonicus, which is the other sea cucumber species widely produced in all over the world. However, many studies on aquaculture of new sea cucumber species are being conducted on all over the world (Santos et al., 2015, Sicuro and Levine, 2011; Tolon et al., 2017).

Holothuria tubulosa is one of the most common and commercial sea cucumber species in the Mediterranean Sea (Ocaña and Tocino, 2005) and a candidate for aquaculture (Tolon et al., 2017). They are extremely demanded due to their rich proximate composition, high protein component and nutritional value (Çakli et al., 2004). Sicuro and Levine (2011), reported that $H$. tubulosa might be one of the potential aquaculture species in the Mediterranean Sea. Recent studies on adaptation of $\mathrm{H}$. tubulosa to aquaculture reported successful results (Günay et al., 2015; Tolon et al. 2015). However, studies on the hatching stages are lacking in the literature.

Stocking density is the most important criteria at hatching stage for production of sea cucumbers (Asha and Diwakar, 2013; Liu et al., 2010; Battaglene and Bell, 1999). Previous studies on $H$. scabra (Asha and Diwakar, 2013), Holothuria scabra versicolor (Ivy and Giraspy, 2006) and A. japonicus (Liu et al., 2010) reported a significant relationship between stocking density and hatching rate. This is the first report in the literature which aims to determine the optimum stocking density of $H$. tubulosa eggs for maximum hatching and survival rate. Therefore, the hatching and survival rates of fertilized sea cucumber H.tubulosa eggs under various stocking densities have been investigated. Moreover, the effects of various stocking densities on the diameter of eggs and larvae size in early auricularia stage have been determined.

Therefore, we investigated the hatching and survival rates of fertilized sea cucumber H.tubulosa eggs under selected stocking densities. Moreover, we determined the effects of various stocking densities on the diameter of eggs and larvae size in early auricularia stage.

\section{MATERIAL AND METHODS}

$H$. tubulosa adults were hand-picked from the Aegean Sea shores of the Ildır village in Izmir city, Turkey $\left(38^{\circ} 23^{\prime} 48.61^{\prime \prime N}-26^{\circ} 28^{\prime} 26.02 " \mathrm{E}\right)$ by scuba-divers. Thirty brooders $(150 \pm 15 \mathrm{~g})$ were induced to spawn by raising water temperature $3-5^{\circ} \mathrm{C}$ above initial temperature of $23^{\circ} \mathrm{C}$ in 1000 I PVC tanks (Battaglene et al., 2002). Since gender of sea cucumbers can not be distinguished from their physical characteristics, only one male continuing to spawn left in the tank. Thus, excessive sperm density in the tank could be prevented. After spawning of females, samples were taken from the water column into a $500 \mathrm{ml}$ beak, the fertilization rate was checked under the microscope and the egg diameters were recorded (at $0 \mathrm{~h}$ ). The fertilized eggs in the water column were then collected in a 70 I collector, by siphoning water through a $80 \mu \mathrm{m}$ sieve and washed to remove excess sperm. Five subsamples were taken from 70 I collector and counted to estimate average density.

The trial was consisted of four stocking densities, selected as 1 (Group A), 5 (Group B), 15 (Group C) and 30 (Group D) eggs/ml. Fertilized eggs were transferred to 30 I trial collectors. Five subsamples were taken from each collector, than counted and diameters of eggs were measured under microscope ( $1^{\text {st }}$ hour $)$.

Trial was carried out in three 30 I cylinder collectors which were covered by $80 \mu \mathrm{m}$ sieve and placed into one 1000 I PVC tanks (Figure 1). Gentle water circulation by continuous flow of filtered sea water was applied. Dissolved oxygen concentration was maintained at $7.6 \pm 0.3 \mathrm{mg} / \mathrm{l}$ by continuous air flow through the air diffusers in all collectors, water temperature and $\mathrm{pH}$ were $23.5 \pm 0.2{ }^{\circ} \mathrm{C}$ and $7.4 \pm 0.1$, respectively. Black covers were placed on top of each tank in order to keep the eggs in dark environment.

The development of fertilized eggs was monitored under the microscope every 4 hours to detect the accurate time for sampling that majority of them are at the same development stage. Initial survival rates (about in one hour), early gastrulation ( $20^{\text {th }}$ hour), late gastrulation ( $45^{\text {th }}$ hour) and hatching rates at early auricularia larvae stage ( $65^{\text {th }}$ hour) have been determined for all groups. The time of sampling was determined when the majority of eggs $(\geq 90 \%)$ were at the same stage in all groups. Egg and larvae samples were taken from 
the water column after pausing the aeration for $1 \mathrm{~min}$ ute. Egg diameter and larvae size were measured by a graduated micrometer eyepiece and compound microscope at 10X magnification. Larvae size was measured from prominent posterior protrusion (p) to anterior commissure (a) (Figure 2). Five $1 \mathrm{ml}$ subsamples were taken from each collector and counted using a Sedgewick-Rafter chamber under a microscope to calculate survival and hatching rate at all sampling times.

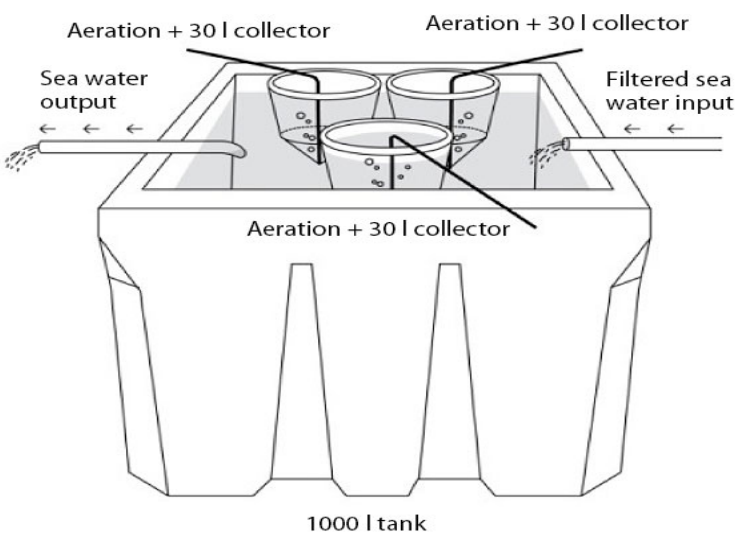

Figure 1. Design of the experimental tank

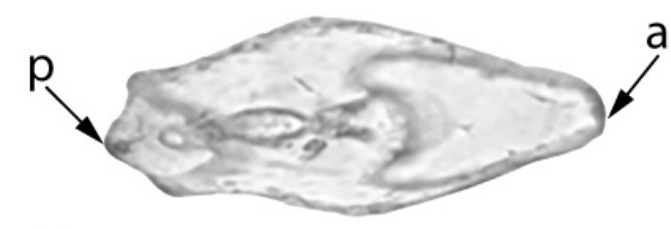

\section{$100 \mu \mathrm{m}$}

Figure 2. Early auricularia larvae of $H$. tubulosa; posterior protrusion ( $\mathrm{p})$, anterior commissure (a)

\section{Statistical analysis}

The data were tested for homogeneity of variance using Levene's test prior to analysis. Normal distribution of the data was tested by Kolmogorov-Smirnov. Arcsine transformation was performed to the data of survival and hatching rates before analysis.

Survival rates $\left(20^{\text {th }}\right.$ and $45^{\text {th }}$ hours), hatching rates (65 $65^{\text {th }}$ hour), egg $\left(1^{\text {st }}, 20^{\text {th }}\right.$ and $45^{\text {th }}$ hours) and larvae size (65 $5^{\text {th }}$ hour) were compared among the trial groups. Data of the groups were analyzed by one-way ANOVA and significant differences between treatments were determined by Duncan's Multiple Range test.

Level of 0.05 was accepted as an indication of statistical significance. Nonparametric Spearman Correlation Analyses were performed to determine the relationship between stocking density and hatching rate. Temperature, $\mathrm{pH}$ and dissolved oxygen values were presented as mean \pm standard deviation (SD). Size of samples, survival and hatching rates were presented as mean \pm standard error (SE).

\section{RESULTS}

Male sea cucumbers started to spawn in the afternoon (16:00-18:00), and females followed them approximately one hour later. Elongations were observed for the measured eggs for all groups after the early gastrulation. More than $90 \%$ of the population in all collectors reached early gastrulation, late gastrulation and early auricularia stages at $20^{\text {th }}, 45^{\text {th }}$ and $65^{\text {th }}$ hours, respectively.

During the study, dead or deformed eggs and larvae stayed very close to the bottom of the tanks in each collector. There were no significant differences between eggs and larvae sizes of all groups $(A, B, C, D)$ per sampling times ( $p>0.05$ ) (Table 1). No differences found in sizes among all treatments but there were significant differences in hatching rates $(p<0.05)$. The lowest hatching rate was observed in group $D$ at $30 \mathrm{eggs} / \mathrm{ml}$ stocking density. An inverse relationship was detected between stocking density and hatching rate according to the results $(r=-0.848 ; p<0.001)$. Hatching rates were $81.1 \pm 1.11,81.6 \pm 1.22,53.3 \pm 0.39$ and $43.1 \pm 0.95 \%$ at stocking densities 1, 5, 15 and 30 eggs/ml, respectively (Figure 3).

Table 1. Size of fertilized eggs $\left(1^{\text {st }}, 20^{\text {th }}\right.$ and $45^{\text {th }}$ hours) and auricularia larvae ( $65^{\text {th }}$ hour) at stocking density groups (mean $\pm S E, n=15$ )

\begin{tabular}{|c|c|c|c|c|}
\hline \multicolumn{5}{|c|}{ Size $(\mu)$} \\
\hline \multirow[b]{2}{*}{ Hour } & Group & Group & Group & Group \\
\hline & A & B & C & D \\
\hline 1 & $252.85 \pm 3.30$ & $255.34 \pm 6.31$ & $252.14 \pm 1.13$ & $252.89 \pm 3.65$ \\
\hline 20 & $253.64 \pm 2.41$ & $253.64 \pm 3.57$ & $245.48 \pm 2.89$ & $247.52 \pm 2.32$ \\
\hline 45 & $398.48 \pm 4.61$ & $405.96 \pm 3.75$ & $391.68 \pm 7.09$ & $390.32 \pm 4.03$ \\
\hline 65 & $492.32 \pm 5.58$ & $493.68 \pm 4.85$ & $480.08 \pm 7.21$ & $496.40 \pm 4.18$ \\
\hline
\end{tabular}

Groups labels indicate: $A=1$ egg $/ \mathrm{ml} ; B=5$ eggs $/ \mathrm{ml} ; C=15$ eggs $/ \mathrm{ml} ; D=30$ eggs $/ \mathrm{ml}$ 


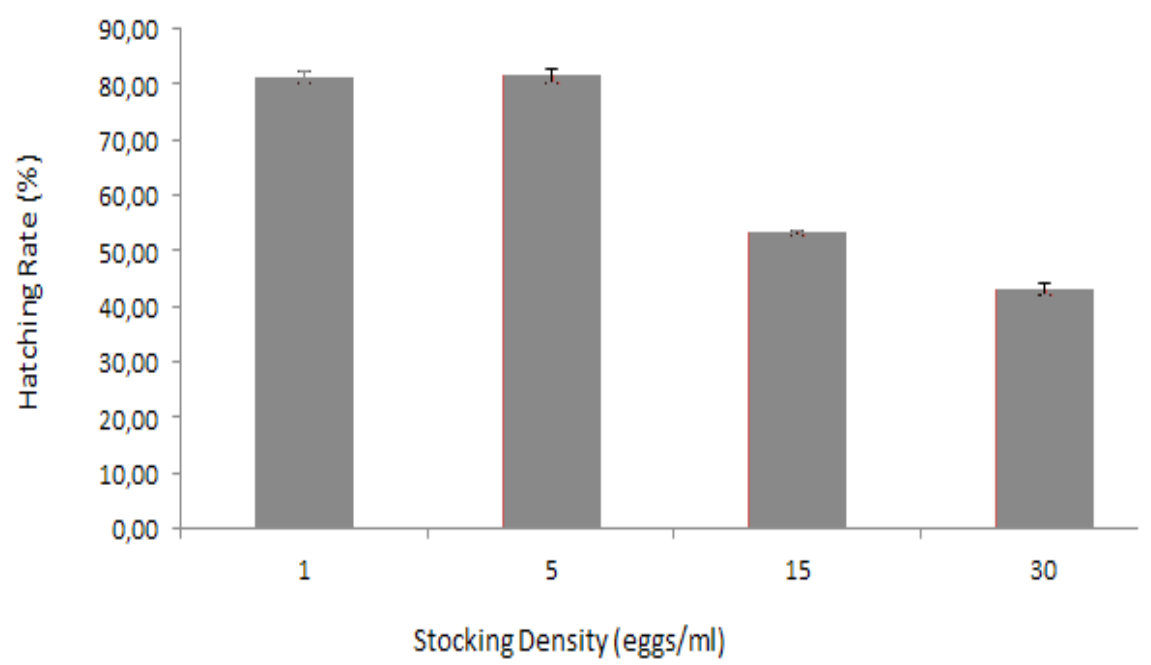

Figure 3. Effect of stocking density (eggs/ml) on hatching rates (\%) of fertilized H. tubulosa eggs

There were no significant differences for survival and hatching rates of group $A$ and $B$ at all sampling times $(p>0.05)$. There were significant differences in survival and hatching rates between group $C$ and $D$ at all sampling times $(p<0.05)$. Group $D$ had the lowest survival rates for all sampling times (Table 2). The stocking density determined as to be maximum 5 eggs $/ \mathrm{ml}$ for fertilized $H$. tubulosa eggs in this study.

Table 2. Survival $\left(1^{\text {st }}, 20^{\text {th }}\right.$ and $45^{\text {th }}$ hours $)$ and hatching rate $\left(65^{\text {th }}\right.$ hour $)$ at eggs incubation time in stocking density groups (mean $\pm \mathrm{SE}, \mathrm{n}=15$ )

\begin{tabular}{lllll}
\hline & & \multicolumn{2}{l}{ Survival and Hatching Rates (\%) } \\
Hour & Group & Group & Group & Group \\
\hline 1 & A & B & C & D \\
\hline 20 & 100 & $97.4 \pm 1.37^{\mathrm{a}}$ & $59.8 \pm 1.03^{\mathrm{b}}$ & 100 \\
45 & $94.4 \pm 5.55^{\mathrm{a}}$ & $92.1 \pm 0.10^{\mathrm{a}}$ & $59.6 \pm 0.68^{\mathrm{b}}$ & $46.7 \pm 1.43^{\mathrm{c}}$ \\
65 & $94.4 \pm 4.56^{\mathrm{a}}$ & $81.6 \pm 1.22^{\mathrm{a}}$ & $53.3 \pm 0.39^{\mathrm{b}}$ & $44.7 \pm 0.50^{\mathrm{c}}$ \\
\hline
\end{tabular}

Groups labels indicate: $A=1 \mathrm{egg} / \mathrm{ml} ; B=5$ eggs $/ \mathrm{ml} ; C=15$ eggs $/ \mathrm{ml} ; D=30$ eggs $/ \mathrm{ml}$. Data with different superscripts in rows are significantly different from each other $(p<0.05)$

\section{DISCUSSION}

The significant relationship between stocking density and hatching rate for sea cucumber species Holothuria scabra (Asha and Diwakar, 2013; James, 1996) and Apostichopus japonicus (Sui, 1989; Yanagisawa, 1998) was mentioned in the previous studies. Conforming to the results of these studies, it was found a significant inverse relationship between stocking density and hatching rates in the groups with high stocking density (groups $\mathrm{C}$ and D) for H. tubulosa eggs in this study. Previous studies on echinoderms reported that gastrula stage is one of the most vulnerable phase to external factors as salinity, temperature and heavy metal ions (Yaroslavtseva et al., 2002; Kashenko, 2005; Pia et al., 2012). Similarly, mortalities were first seen in early gastrulation in this study especially in high stocking rates, groups $\mathrm{C}$ and $\mathrm{D}$. Dissolved oxygen, $\mathrm{pH}$ and temperature parameters were kept at optimum levels during the study. Big differences in temperature avoided as described by Agudo (2016), pH and dissolved oxygen were also kept in optimum range (Agudo, 2016; James et al., 1994).

Therefore, low survival rate caused by high stock density observed at the first development stage. The results of this study advising low stocking densities like 1-5 eggs/ml for successful breeding of $H$. tubulosa. These stocking densities reported in this study is similar with the findings of Ramofafia et al. (1995) (2.7 eggs/ $\mathrm{ml}$ for Holothuria atra), Agudo (2006) (0.3-1 eggs $/ \mathrm{ml}$ for Holothuria scabra) and Guisado et al. (2012) (3 eggs $/ \mathrm{ml}$ for Athyonidium chilensis).

Similar with the report of Pitt et al. (2001), precise- 
ly cleaned and gently handled fertilized eggs can be incubated up to $5 \mathrm{eggs} / \mathrm{ml}$, under the determined temperature, dissolved oxygen and $\mathrm{pH}$ levels of this study. In contrast, Asha and Diwakar (2013) reported the highest $(66.4 \%)$ and lowest $(22.6 \%)$ hatching rates at 0.5 eggs $/ \mathrm{ml}$ and 6 eggs $/ \mathrm{ml}$ stocking densities for $H$. scabra eggs, respectively. In this study high hatching rates were observed for H.tubulosa eggs in both low stocking density groups ( 1 and 5 eggs $/ \mathrm{ml}$ ). Therefore, it can be concluded that stocking densities up to 5 eggs/ $\mathrm{ml}$ do not critically influence the hatching rates of $H$. tubulosa eggs in this study.

Liu et al. (2010) reported over $80 \%$ hatching rate and no significant differences among $0.2,0.5,1,2,5$ and 10 eggs $/ \mathrm{ml}$ stocking densities groups where the significant differences appeared at 20 and 50 eggs $/ \mathrm{ml}$ stocking densities for Apostichopus japonicus. Similarly, hatching rates at 15 and 30 eggs/ml stocking densities were found lower than the other density groups for

\section{REFERENCES}

Agudo, N. (2006). Sandfish hatchery techniques. Australian Centre for International Agricultural Research (ACIAR), The Secretariat of the Pacific Community (SPC) and the World Fish Centre. Noumea: New Caledonia.

Asha, P. \& Diwakar, K. (2013). Effect of stocking density on the hatching rate, larval and early juvenile rearing of edible sea cucumber Holothuria scabra (Jaeger, 1883). Indian Journal of GeoMarine Science, 42, 191-195.

Battaglene S. C., Seymour, J. E. Ramofafia, C \& Lane, I. (2002). Spawning induction of three tropical sea cucumbers, Holothuria scabra, $\mathrm{H}$. fuscogilva and Actinopyga mauritiana. Aquaculture, 207(1), 29-47. DOI:10.1016/S0044-8486(01)00725-6

Battaglene S. C. \& Bell, J. D. (1999). Potential of the tropical IndoPacific seacucumber, Holothuria scabra, for stock enhancement. In B.R. Howell, E. Moskness, T. Svasand (Eds.), Proceedings of the First International Symposium on Stock Enhancement and Sea Ranching (pp 478-490). Blackwell, Oxford.

Choo P. S. (2008). Population status, fisheries and trade of sea cucumbers in Asia. In: V., Toral-Granda, A. Lovatelli, M. Vasconcellos, M. (Eds.), Sea cucumbers A global review of fisheries and trade (pp 81-118). Rome: FAO Fisheries and Aquaculture Technical Paper No.516.

Çakli S., Cadun, A., Kışla, D. \& Dinçer, T. (2004). Determination of quality characteristics of Holothuria tubulosa, (Gmelin, 1788) in Turkish sea (Aegean Region) depending on sun drying process step used in Turkey. Journal of Aquatic Food Product Technology, 13(3), 69-28. DOI: 10.1300/J030v13n03 07

Dabbagh, A. R., Sedaghat, M. R., Rameshi, H. \& Kamrani, E. (2011). Breeding and larval rearing of the sea cucumber Holothuria leucospilota Brandt (Holothuria vegabunda Selenka) from the northern Persian Gulf, Iran. SPC Beche-de-mer Information Bulletin, 31, 35-38.

FAO (2017). Fisheries and Aquaculture Department. Retrieved from http://www.fao.org/fishery (23.04.2017).

Gamboa R., Gomez, A. L. \& Nievales, M. F. (2005). The status of sea cucumber fishery and mariculture in the Philippines. In: A Lovatelli, C. Conand, S. Purcell, S. Uthicke, J.F. Hamel, A. Mercier (Eds): Advances in sea cucumber aquaculture and management (pp 69-78). Rome: FAO Fisheries Technical Paper No.463.
H.tubulosa, in this study.

In conclusion, selected stocking densities had no significant effect on hatching time and size of $H$. tubulosa eggs in this study. Although, synchronized embryonic development stages observed in all groups, high mortality and low hatching rates recorded at high stocking density groups like 15 and 30 eggs $/ \mathrm{ml}$. The stocking density of 1-5 eggs/ml is determined as optimum and strongly suggested for highest hatching and survival rate of fertilized sea cucumber $H$. tubulosa eggs

\section{ACKNOWLEDGEMENT}

This research is funded by Ege University Science and Technology Centre (EBILTEM) and Çamlı Yem Besicilik Sanayi ve Ticaret A.Ş. Project Number: 2012/ BiL/030. The authors would like to thank Ege University Faculty of Fisheries (Izmir, Turkey), EBILTEM and Çamlı Yem Besicilik Sanayi ve Ticaret A.Ş. (Izmir, Turkey) for funding and research facilities.

Guisado C., Carrasco, S.A., Guisado, D.D., Maltrain, R. \& Rojas, H. (2012). Embryonic development, larval morphology and juvenile growth of the sea cucumber Athyonidium chilensis (Holothuroidea: Dendrochirotida). Revista de Biología Marina y Oceanografía, 47(1), 65-73.

Günay D., Emiroglu, D., Tolon, T., Ozden, O. \& Saygi, H. (2015). Growth and Survival Rate of Juvenile Sea Cucumbers (Holothuria tubulosa, Gmelin, 1788) at Various Temperatures. Turkish Journal of Fisheries Aquatic Sciences, 15, 533-541. DOI: 10.4194/1303-2712-v15_2_41

Ivy G. \& Giraspy, D. A. B. (2006). Development of large-scale hatchery production techniques for the commercially important sea cucumber Holothuria scabra veriscolor (Conand, 1986) in Queensland, Australia. SPC Beche-de-Mer Information Bulletin, 24 28-34.

İsgören-Emiroglu, D. \& Günay, D. (2007). The effect of sea cucumber Holothuria tubulosa G. 1788 on nutrient and organic matter contents of bottom sediment of oligotrophic and hypereutrophic shores. Fresenius Environment Bulletin, 16, 290-294.

James, D. B., Gandhi, A. D., Palaniswamy, N., \& Rodrigo, J. X. (1994). Hatchery techniques and culture of the sea-cucumber Holothuria scabra. CMFRI Special Publication, 57, 1-40.

James D. (1996). Culture of sea-cucumber. Bulletin of Central Marine Fisheries Research Institute, 48, 120-126.

Kashenko S. D. (2005). Responses of Embryos and Larvae of the Starfish Asterias amurensis to Changes in Temperature and Salinity. Russian Journal of Marine Biology, 31(5), 294-302. DOI: 10.1007/s11179-005-0091-9

Liu G., Yang, H. \& Liu, S. (2010). Effects of rearing temperature and density on growth, survival and development of sea cucumber larvae, Apostichopus japonicus (Selenka). Chinese Journal of Oceanology and Limnology, 28(4), 842-848. DOI: 10.1007/s00343-010-9092-4

Morgan, A. D. (2009). Assessment of egg and larval quality during hatchery production of the temperate sea cucumber, Australostichopus mollis (Levin). Journal of World Aquaculture Society, 40(5), 629-642.DOI: 10.1111/j.1749-7345.2009.00283.x

Ocaña A. \& Tocino L. S. (2005). Spawning of Holothuria tubulosa (Holothurioidea, Echinodermata) in the Alboran Sea (Mediterranean Sea). Zoologica Baetica, 16, 147-150. 
Pia T. S., Johnson, T \& George, S.B. (2012). Salinity-induced morphological changes in Pisaster ochraceus (Echinodermata: Asteroidea) larvae. Journal of Plankton Research, 34(7), 590-601.

Pitt R., Thu, N., Minh, M. \& Phuc, H. (2001). Preliminary sandfish growth trials in tanks, ponds and pens in Vietnam. SPC Beche-demer Information Bulletin, 15, 17-27.

Purcell S. W., Hair C.A. \& Mills D.J. (2012). Sea cucumber culture, farming and sea ranching in the tropics: Progress, problems and opportunities. Aquaculture, 368, 68-81. DOI: 10.1016/j. aquaculture.2012.08.053

Purcell S. W., Mercier, A. \& Conand, C. (2013). Sea cucumber fisheries: Global analysis of stocks, management measures and drivers of overfishing. Fish and Fisheries, 14(1), 34-59. DOI: 10.1111/j.1467-2979.2011.00443.x

Raison C. (2008). Advances in sea cucumber aquaculture and prospects for commercial culture of Holothuria scabra. CAB Reviews, 3(82), 1-15. DOI:10.1079/PAVSNNR20083082

Ramofafia C., Gervis, M. \& Bell, J. (1995). Spawning and early larval rearing of Holothuria atra. SPC Bêche-de-mer Information Bulletin, 7, 2-6.

Santos R., Dias S., Pinteus S., Silva J., Alves Tecelao C., Pedrosa R. \& Pompo A. (2015). Sea cucumber Holothuria forskali, a new resource for aquaculture? Reproductive biology and nutraceutical approach. Aquaculture Research, 47, 2307-2323. DOI: 10.1111/are.12683

Sicuro B., Levine J. (2011). Sea cucumber in the Mediterranean: a potential species for aquaculture in the Mediterranean. Reviews in Fisheries Science, 19(3), 299-304.

Sui, X. (1989). The main factors influencing the larval development and survival rate of the sea cucumber Apostichopus japonicus. Oceanologia Et Limnologia Sinica, 4, 314-321.

Tolon T., Emiroglu D., Günay D. \& Saygi, H. (2015). Effect of Sediment Grain Size on Growth Performance of Juvenile Sea Cucumber (Holothuria tubulosa). Turkish Journal of Fisheries Aquatic Sciences, $15,555-559$.

Tolon T., Emiroğlu D., Günay D. \& Hancı (2017). Effect of stocking density on growth performance of juvenile sea cucumber Holothuria tubulosa (Gmelin, 1788). Aquaculture Research, 48(8), 4124-4131. DOI: $10.1111 /$ are.13232

Tuwo A. \& Tresnati J. (2015). Sea Cucumber Farming in Southeast Asia (Malaysia, Philippines, Indonesia, Vietnam). In: N. P. Brown, S.D. Eddy (Eds): Echinoderm Aquaculture (pp 331-352). USA: John Wiley \& Sons

Yanagisawa T. (1998). Aspects of the biology and culture of the sea cucumber. In: S. S. De Silva (Ed.): Tropical Mariculture (pp 291-308). London: Academic. DOI: 10.1016/B978-012210845-7/50009-X

Yaroslavtseva L. M. \& Sergeeva, E.P. (2002). Sensitivity of embryos and larvae of the sea urchin Strongylocentrotus intermedius to effects of copper ions. Russian Journal of Marine Biology, 28(6), 393-397. DOI: 10.1023/A:1021801231005 